\title{
KECAMAN TUHAN TERHADAP DOSA YEHUDA BERDASARKAN PENAFSIRAN YESAYA 1:10-20 DAN RELEVANSINYA
}

\author{
Herrio Tekdi Nainggolan \\ Fakultas Teologi Universitas Kristen Satya Wacana \\ Jln. Diponegoro 52-60 Salatiga 50711 \\ Email: herrio911@gmail.com
}

\begin{abstract}
God's Censure of the Sins of Judah (The Interpretation of Isaiah 1:10-20) and its relevance for Churches. The writing of this article will eksplore the social problems that happened in the South of Israel (Judah). With using qualitative method hermeneutical approach, this writing will excavate the meaning of the God's censure of the sins of the Judah in Isaiah 1:10-20, in order to get it's relevance for the current churches. Based on the research, the meaning of God's censure the sins of Judah in Isaiah 1: 10-20 is that the people of Judah assume that the LORD will deal with their official and lively worship, while they forget and oppress their fellow humans. For God, all of that is a form of evil and showing self-deceitful piety. Their crime is proven by the rise of social injustice, namely the oppression of the weak such as the poor, widows and orphans. So through the prophet Isaiah, the Lord firmly censure them and said that the worship they performed, the offering of the sacrifice they gave and the prayers they offered were something that was burdensome and disgusting to God. Judah was found guilty before God and had to turn to God's law and will. God censure the sins of Judah because all of them both leaders and people had insulted the holy God.
\end{abstract}

Keyword: God's Censure, Sin, Justice, Relevance, Churches

\begin{abstract}
Abstrak: Kecaman Tuhan terhadap Dosa Yehuda (Penafsiran Yesaya 1:10-20) dan Relevansinya bagi Gereja. Penulisan artikel ini akan menelisik masalah sosial yang terjadi di Israel Selatan (Yehuda) pada masa pelayanan nabi Yesaya. Dengan menggunakan metode kualitatif pendekatan hermeneutik, tulisan ini akan menggali lebih mendalam makna kecaman Tuhan atas dosa kaum Yehuda dalam Yesaya 1:1020, sehingga dapat menemukan relevansinya bagi gereja masa kini. Dari penelitian yang dilakukan, maka kecaman Tuhan terhadap dosa Yehuda dalam Yesaya 1:10-20 adalah kaum Yehuda beranggapan bahwa TUHAN akan berkenan dengan ibadah-ibadah mereka yang resmi dan meriah, sementara mereka melupakan dan menindas sesamanya manusia. Bagi Tuhan, semuanya itu adalah bentuk kejahatan dan pamer kesalehan diri yang menipu. Kejahatan mereka terbukti dengan maraknya ketidakadilan sosial, yaitu penindasan terhadap kaum lemah seperti orang miskin, para janda dan anak yatim. Maka melalui nabi Yesaya, dengan tegas Tuhan mengecam mereka dan mengatakan bahwa ibadah-ibadah yang mereka lakukan, persembahan korban yang mereka berikan dan doa-doa yang mereka sampaikan adalah sesuatu yang membebani dan menjijikkan bagi TUHAN. Yehuda dinyatakan bersalah di hadapan Tuhan dan harus berbalik kepada hukum dan kehendak TUHAN. Tuhan mengecam dosa Yehuda karena mereka semua baik pemimpin maupun umat telah menghina Allah yang kudus.
\end{abstract}

Keyword: Kecaman Tuhan, Dosa, Keadilan, Relevansi, Gereja

\section{PENDAHULUAN}

Nabi-nabi abad kedelapan digelisahkan oleh perubahan sosial yang mereka amati. Mereka memiliki keperihatinan yang mendalam terhadap ketidakadilan sosial yang sedang terjadi (Stanislaus, 2018, p. 71). Pada abad inilah nabi Yesaya dipanggil dan melayani di kerajaan Israel selatan (Yehuda), dimana saat itu adalah zaman yang makmur di Timur Tengah termasuk di Israel dan Yehuda. Raja Uzia
(Azarya) yang memerintah kerajaan Yehuda di selatan adalah raja yang makmur dan giat (Boyd, 2000, p. 39). Dalam banyak hal, pemerintahannya mengimbangi pemerintahan Yerobeam di kerajaan utara. Ia membentuk bala tentara, membangun perbentengan, membuat jalan-jalan perdagangan dan mengadakan banyak persekutuan politik (2 Taw. 26). Bagi raja Uzia, inilah masa perluasan, kemerdekaan, dan kemakmuran. Uang mengalir masuk, angkatan p- 
erangnya senantiasa menang sehingga rakyat bangga dengan angkatan perang dan prestasinya itu. Tak seorangpun yang merasa cemas dan takut akan serangan dari luar (Hill \& Walton, 2001, p. 526).

Akan tetapi di tengah-tengah situasi yang penuh dengan kemakmuran dan pertambahan kekayaan yang mencengangkan itu, terjadi pemborosan dan kesenangan diri oleh golongan penguasa. Sementara golongan orang miskin ditindas dan diperhambakan dan seluruh tanah sebagai sumber penghidupan bagi kaum miskin, menjadi milik beberapa orang saja. Kalangan saudagar memperoleh banyak uang dan merebut tanah sehingga hasil tanah hanya untuk kalangan tertentu. Hakim-hakim tidak jujur dan pemerintahan rusak. Riba, pemerasan dan huru hara dan kebencian antar golongan nyata pada segala aspek. Orang kaya memperoleh kekayaan dengan jalan ketidakadilan dan penindasan. Mereka mengambil keuntungan dari para petani miskin dan menjebak dalam utang, dan akhirnya menyita hak milik, karena tidak dapat membayar utang (Stanislaus, 2018 , p. 67). Kaum buruh di ladang menjadi semakin miskin dan menderita oleh para tuan tanah yang kejam dan para lintah darat yang tidak berbelaskasihan, sehingga kesedihan orang-orang miskin tidak tertahankan. Snell (2009, p. 41) menambahkan, tak seorangpun di antara kaum hartawan yang memperdulikan golongan yang menderita. Istri tuan tanah yang tidak mengenal kasihan sama seperti suaminya menuntut begitu banyak dari suaminya, sehingga sebaliknya mereka menimbun beban-beban yang baru bagi orang dusun. Kaum Yehuda lupa dan mengabaikan bahwa keadilan sosial menjadi bagian yang sangat penting dalam perjanjian antara Allah dan umat Israel (Stanislaus, 2018, p. 67). Itulah sebabnya, Yesaya mengkritik dengan keras tindakan-tindakan para pemimpin dan kaum Yehuda (Vriezen, 2003, p. 87).

Dalam bidang keagamaan, mereka mempraktikkan sikap ikut-ikut saja dalam ibadah tanpa menghayati prinsip-prinsip iman, bahkan kadang-kadang kemurtadan yang membawa pada penyembahan berhala dan keterlibatan dalam takhayul. Ye- saya mengecam mereka, dan mengatakan bahwa dosa mereka yang paling besar bukanlah dosa kriminal, melainkan tidak adanya kesadaran akan dosa kemunafikan itu. Kehidupan keagamaan dan kultus mereka telah dimanipulasi dengan kegiatan-kegiatan ritual keagamaan yang munafik yang dilakukan untuk memuaskan diri sendiri, sebagai wujud pamer kesalehan diri. Hal itu diperlihatkan dengan banyaknya korban persembahan, maraknya pesta-pesta perayaan yang meriah, serta mereka menaikkan doadoa yang panjang dan sebagainya. Akan tetapi, janda, yatim piatu dan orang-orang miskin ditelantarkan (Widyapranawa, 2012, p. 13). Dosa Yehuda yang begitu kompleks baik pemimpin maupun umat menjadi kecaman Yesaya dan menyerukan agar Yehuda kembali kepada kehendak Allah.

Dari pihak pemimpin, Ahaz selaku raja di Yehuda saat itu, lebih percaya kepada kekuatan bangsa asing dari pada kekuatan Allah. Hal ini terbukti ketika ia dan umat melakukan penyembahan berhala dan adanya pengaruh-pengaruh lain dari agama kafir. Dalam hal ini, Ahaz telah melanggar hukum Allah. Dia menyinggung tempat-tempat penyembahan (Yes.1:29) dan praktik-praktik kafir tertentu, termasuk sihir (Yes.2:6) dan bertanya kepada arwah orang mati (Yes.8:19). Bukannya mencari bimbingan dari Allah, rakyat itu malah berusaha menghubungi arwah orang-orang mati (Pandia, 2016, p. 9).

Melihat apa yang terjadi pada masa dan konteks pelayanan nabi Yesaya di Yehuda, secara nyata juga terjadi di Indonesia. Sampai saat ini, kemiskinan dan kesenjangan sosial di negeri ini khususnya di daerah-daerah Indonesia Timur yang merupakan basis kekristenan, menjadi permasalahan kemanusiaan yang serius sehingga perlu ditanggapi dan dipikirkan oleh pemerintah, khususnya oleh gereja. Dalam hal ini, gereja sebagai lembaga keagamaan sekaligus lembaga sosial bukanlah berkedudukan sebagai oposisi apalagi musuh bagi pemerintah, tetapi mitra sehingga gereja memiliki peran dan fungsi yang strategis untuk menyikapi masalah ketidakadilan sosial yang ada (Susanto, 2019. p. 40). 


\section{METODE}

Metode penelitian yang digunakan dalam penulisan ini adalah penelitian kualitatif dengan pendekatan penafsiran historis kritis yang dikembangkan oleh A. A Sitompul dan U. Bayer dalam buku yang berjudul Metode Penafsiran Alkitab (Sitompul \& Beyer, 2002). Metode ini dilakukan dengan mengumpulkan data-data sebagai fakta yang benar melalui sumber-sumber literatur. Lumintang (2016, p. 99) mengatakan, pendekatan kualitatif adalah suatu pendekatan yang dibangun di atas landasan filsafat atau paradigma fenomenologi dengan menggunakan karakteristik penelitian alamiah, dengan pandangan bahwa realitas bersifat terbuka, kontekstual, jamak, menyeluruh dan terikat satu dengan yang lain, mengenai pengalaman individu dan komunal, makna secara sosial dan historis dibangun dengan maksud mengembangkan teori atau model atau pola pandangan objek penelitian, dengan menggunakan metode analisis isi, etnografi, fenomenologis, studi kasus, dan grounded theory.

Sehingga langkah-langkah yang dipakai penulis; pertama, menganalisis teks Yesaya 1:10-20, membandingkan terjemahan beberapa versi; seperti versi Lembaga Alkitab Indonesia (LAI), King James Version (KJV), Terjemahan Baru (TB) dan terjemahan harfiah, kemudian memperbaiki terjemahan dalam bahasa Indonesia apabila dibutuhkan untuk mendapatkan hasil terjemahan yang lebih mendekati teks aslinya. Diikuti dengan kritik teks untuk melihat bagian teks yang sedang dipermasalahkan oleh berbagai naskah dan penafsiran. Perbandingan terjemahan dimaksudkan untuk memperoleh dan memperjelas makna kata yang berbeda dalam penerjemahan, lalu disimpulkan untuk memperjelas teks yang ada. Penerjemahan dilakukan dengan menggunakan buku acuan analitical dan exegetical bahasa asli, kamus Ibrani, aplikasi Bible Works versi 10 dan lain-lain. Sedangkan sumber utama untuk melihat dan melakukan penafsiran ini merujuk pada tafsiran kitab Yesaya oleh Bergant dan Karris dalam buku Tafsir Alkitab Perjanjian Lama dan karya Oswalt dalam buku The New International Commentary on the Old Testament; The Book Isaiah Chapter 1-39".

Langkah kedua, meneliti konteks sejarah dari nats yang diteliti. Kemudian membuat garis besar eksegesis berdasarkan terjemahan yang dikerjakan dalam langkah pertama. Ketiga, menyusun komentar eksegesis berdasarkan garis besar yang telah dibuat. Keempat, membuat analisis data, temuan dan hasil dari teks yang diteliti. Dengan menggunakan bantuan buku-buku, melihat berbagai tafsiran, membandingkan pendapat para ahli, maka penulis membuat kesimpulan yang lebih memadai dan akurat. Setelah melakukan dan menghubungkan langkahlangkah tersebut di atas, dari perikop yang ditafsir maka akan diperoleh hasil yang disebut temuan dan menghasilkan relevansi bagi gereja masa kini.

\section{HASIL DAN PEMBAHASAN}

\section{Sitz In Leben (Setting In Life)}

\section{Konteks Politik}

Yesaya melayani di Yehuda pada zaman pemerintahan raja-raja Uzia, Yotam, Ahaz dan Hizkia, (Yes. 1:1). Waktu nabi Yesaya tampil di negeri Yehuda, kerajaan 10 suku bangsa yang di sebelah utara (Israel) sedang menuju keruntuhannya di bawah kekuasaan bangsa Asyur, setelah berpaling dari Tuhan selama 200 tahun, dan diperintah oleh tidak kurang dari 19 raja yang berasal dari 8 keluarga. Untuk menghadapi ancaman raja Asyur (Tiglat Pileser II), raja-raja di tanah Palestina dan Siria berusaha membentuk satu persekutuan yang dikepalai oleh Damaskus, ibu kota negeri Siria. Ahaz, raja Yehuda tidak mau bergabung dalam persekutuan ini. Karena itu, Israel dan Siria bersatu untuk menyerang negeri Yehuda dan hendak memaksa raja Ahaz. Raja Ahaz kemudian meminta bantuan kepada negeri Asyur. Raja Asyur datang dengan kekuatan bala tentara yang besar dengan mengalahkan Siria dan Israel (Gemeren, 2007, p. 279). Akibat memanasnya situasi politik di Timur Dekat Kuno abad kedelapan, para pemimpin cenderung menjalankan 
pemerintahan dengan sistem penguasaan. Jabatan mereka sebagai pemimpin lebih bersifat kepada penindasan (nōgéśâyw) dan mereka dimotivasi hanya oleh keuntungan pribadi. Secara khusus di kerajaan selatan yang beribukota di Yerusalem, tuduhan nabi Yesaya kepada mereka bahwa para pemimpin kaum Yehuda melakukan eksploitasi terhadap rakyat kecil (Couey, 2014, p. 100). Akibatnya, keamanan dan stabilitas negara menjadi tidak menentu dan rakyat biasa menjadi korban. Di kerajaan utara, Asyur menyerang Israel dan menahan rajanya serta mengambil tanahnya, tetapi tidak berhasil menaklukkan ibukotanya Samaria. Namun setelah tiga tahun pengepungan, Samaria jatuh (721 SM), dan sisa orang Israel dibawa sebagai tawanan. Dengan jatuhnya kerajaan Israel, Asyur telah memperluas daerah kekuasaannya sampai ke perbatasan utara Yehuda. Dengan demikian negeri Yehuda menjadi jajahan negeri Asyur (Lasor, Hubbard, \& Bush, 2012, p. 257).

Negeri Yehuda menjadi daerah jajahan kerajaan Asyur hingga pemberontakan raja Hizkia (2 Raj. 18). Pemberontakan itu disetujui Yesaya, yang senantiasa menganjurkan supaya berharap kepada Tuhan saja, dan jangan sekali-kali bersekutu dengan negara asing. Tetapi di kemudian hari, raja Hizkia tidak menuruti anjuran itu, ia lebih mendengar perkataan orang lain, yang mengajak bersekutu dengan Mesir, negara yang satu-satunya berimbang kekuatannya dengan Asyur pada waktu itu (Yes. 30:2-4). Ketika raja Asyur datang melakukan perlawanan, Mesir tidak mengirim bantuan, kemudian tanah Yehuda berhasil diduduki musuh. Raja Hizkia terpaksa membayar banyak emas dan perak, dan tanah Yehuda kembali menjadi daerah jajahan Asyur (2 Raj. 18:13-16). Akhirnya Hizkia berbalik, dan ia mendengarkan anjuran Yesaya sehingga Asyur ditimpa malapetaka yang hebat. Negeri Yehuda bebas dari ancaman musuh, dan menikmati keadaan aman dan tentram (Baxter, 2002, p. 202).

\section{Konteks Sosial-Ekonomi}

Snell (2009, p. 164) mengatakan keadaan sosial-politik di Yehuda seperti yang digambarkan di atas, menguntungkan bagi para pengusaha dan penguasa. Melalui lautan mereka mengadakan hubungan dagang dengan Arabia Selatan. Hal itu menambah potensi dan kekayaan negara yang sangat pesat. Akibatnya timbullah golongan pedagang yang kaya dan berpengaruh sekali. Golongan kapitalis ini mempengaruhi para pemimpin dan pejabat, sehingga menimbulkan gejolak-gejolak sosial dan kemerosotan moral, jurang kesenjangan antara si kaya dan si miskin kian melebar, pelecehan keadilan dan kebenaran nyata di segala aspek kehidupan. Perlakuan orang-orang yang berkuasa adalah merebut dan memperoleh tanah dengan pencabutan hak milik dari para petani miskin, dan rupanya tanah pertanian di Yehuda tidak sesubur di Utara. Kebanyakan tanah pertanian yang produktif dimiliki oleh pribadi-pribadi tertentu saja dan dikerjakan oleh keluarga-keluarga pribadi yang memiliki budak-budak. Budak mungkin tidak banyak jumlahnya, namun keadaan mereka sangat memperihatinkan, mereka jatuh ke dalam perbudakan karena utang yang tak mampu dibayar. Maka kreditur meminta agar mereka membayar dengan diri mereka, dengan bekerja dan menjadi budak (Bullock, 2014, p. 34).

Selain bertani, beternak merupakan pencaharian yang paling menguntungkan bagi para petani yang menetap untuk menyimpan bahan persediaan bahan makanan dan mempersiapkan diri dalam menghadapi kegagaalan panen pada tahun-tahun buruk, sebab kawanan ternak tidak begitu terpengaruh secara langsung oleh musim kemarau seperti hasil panen. Beternak mungkin merupakan salah satu cara menghindarkan diri dari pajak manakala pemerintah cukup kuat untuk mengumpulkannya. Para petani dapat menggiring ternaknya pergi jauh ketika mendengar pemungut pajak akan datang. Mereka dapat menjual ternak untuk membeli tanah dan ternak juga berguna untuk membajak dan mengangkut barang-barang yang berat (Snell, 2009, p. 236).

\section{Konteks Keagamaan}


Dalam bidang keagamaan, dibandingkan di kerajaan Utara yang ibadah mereka sangat kuat dipengaruhi oleh agama-agama Kanaan dan memang sama sekali asing bagi Tuhan, situasi di Yehuda lebih baik dalam perkembangan Yahweisme (Saragih, 2014, p. 60). Selama masa pemerintahan raja Uzia, tidak terjadi penyelewengan-penyelewengan pokokpokok agama Yahweisme. Raja Uzia membela Yahweisme di seluruh negeri, bukan saja hanya di Yerusalem, melainkan juga di bukit-bukit pengorbanan. Tetapi ternyata Yesaya tetap memiliki keluhan. Dia mendakwa penyelewengan-penyelewengan dalam bidang kultus (mis. Yes.2:6; 6:19; 31:7), tetapi lebih mendalam dari pada itu, dia mengeluh bahwa tidak ada rasa khusyuk atau kesadaran dalam ibadat. Ada sikap menghitung-hitung dalam melayani Yahweh, kemunafikan dan ketidakpercayaan (Vriezen, 2003, p. 236). Ketidakpercayaan kepada Yahweh terbukti ketika mereka bertanya kepada roh-roh orang mati dan melakukan pertenungan (Yes.2:29).

\section{Tuhan Memperingatkan Kaum Yehuda}

Dalam ayat 10, nabi Yesaya mulai melakukan pelayanannya, ia memperingatkan penghukuman Allah yang akan menimpa mereka. Kata "dengarlah dan perhatikanlah" merupakan kata kerja imperatif yang terjadi secara berulang. Seruan yang berulang-ulang ini bukan saja sebagai peringatan biasa, tetapi peringatan yang mengarah pada ancaman. Dalam konteks ini seruan untuk memberi pendengaran bisa mengacu pada 1) Kitab Suci, 2) khotbah para nabi, 3) ajaran-ajaran para Imam, dan 4) kumpulan hukum-hukum lainnya yang berlaku (Utley, 2010, p. 27).

Dalam hal ini ada perbedaan penerjemahan yang cukup signifikan yaitu terjemahan KJV memakai give ear, sementara terjemahan bahasa Indonesia versi Terjemahab Baru maupun terjemahan harfiah memakai kata perhatikan. Dapat dipahami secara literal dan berdasarkan makna kata, maka kata give ear berbeda dengan kata perhatikan. Kata perhatikan berarti mengingatkan supaya mendengar dan sebatas mendengar tetapi kata give ear berarti ada penekan- an pada kata give yang berarti memberikan pendengaran dengan sangat serius/ada proses berpikir dan teliti serta memfokuskan diri terhadap objek yang didengarkan. Maka kata give ear yang dipakai terjemahan KJV lebih tepat dibanding dengan kata perhatikan yang dipakai oleh TB dan terjemahan harfiah. Oleh karena itu, nabi Yesaya tidak henti-hentinya menegaskan dan memperingatkan umat, bahwa kalau Allah tidak berbelaskasihan, maka kehancuran akan menimpa mereka. Yesaya sebagai orang yang tidak memiliki kepentingan apapun dalam hal ini, dalam artian ia sendiri tidak diminta oleh siapa pun kecuali karena Tuhan dan tuntutan keadilan dari diri sang nabi.

Dalam konteks Israel, seruan untuk melakukan keadilan yang termuat dalam kumpulan hukumhukum Israel, bukan semata-mata pemberian peraturan untuk ditaati tetapi harus memiliki fungsi dan peran secara nyata dalam hidup sehari-hari. Hal ini mengatur bagaimana seharusnya umat memperlakukan sesamanya dengan benar dan adil. Lebih lagi, hal ini bukan hanya masalah keadilan dalam aspek moral, tetapi juga berbicara tentang keadilan dalam aspek teologi (Mamahit, 2010, p. 6).

Karena dosa dan kejahatan sosial Yehuda ini, mereka disamakan seperti Sodom dan Gomora, dimana kedua kota ini adalah kota yang selalu diasosiasikan sebagai kota yang penuh dengan dosa dan kejahatan (Ngahu, 2019, p. 22). Kemakmuran materi di kota ini memperlihatkan kecongkakan mereka seperti makanan yang berlimpah-limpah dan penduduknya mempraktekkan kesenangan hidup tetapi tidak menolong orang yang sengsara dan miskin. Kota ini juga secara eksplisit dikaitkan dengan apa yang tidak saleh, yang jahat, kekacauan termasuk untuk menggambarkan moral yang rendah. Dalam hal ini dapat dipahami bahwa kaum Yehuda telah melakukan dosa dan kejahatan yang sangat serius sehingga disamakan seperti kota Sodom dan Gomora.

\section{Tuhan Menolak Ritual Keagamaan Yehuda}




\section{Persembahan Korban}

Kaum Yehuda memang mengunjungi Bait Suci dan mempersembahkan korban persembahan di sana, tetapi hal itu mereka lakukan sebagai bentuk pamer kesalehan diri. Yesaya mempertanyakan tujuan mereka melakukan itu dan mengatakan 'siapa yang menginginkan itu dari tangan mereka?' Sebab Tuhan sudah pasti tidak menginginkannya. Pernyataan menginjak-injak pelataran-Ku mengindikasikan kemarahan Tuhan. Allah tidak ingin mereka tampil di hadapan-Nya, sebab Dia tidak menginginkan korban persembahan dari hasil rampasan. Pemberian itu tidak berdampak pada nilai-nilai kebenaran dan keadilan, sebab itu semua adalah kebohongan serta tipu muslihat mereka. Karena mereka tidak melakukan apa yang Tuhan perintahkan, maka dengan tegas Ia melarang mereka melanjutkannya. Hal ini dengan jelas tergambar pada ayat 13a (terjemahan TB), "Jangan lagi (teruskan) membawa persembahanmu yang tidak sungguh, sebab baunya adalah kekejian bagi-Ku."

Mempersembahkan korban yang mereka lakukan merupakan tindakan yang sia-sia, yang munafik, yang mana tindakan itu seakan-akan untuk menutupi dosa dan kesalahan yang diperbuat. Itu berarti Tuhan direndahkan oleh persembahan korban yang mereka berikan dalam ibadat-ibadat perayaan. Korban-korban persembahan jenis domba yang mereka bawa adalah seperti sapi jantan (pârim), betis hewan piaraan (meri'im) yang digemukkan, spesies lembu (bakar); anak domba (cebâshim), kambing jantan (atturim), kambing muda yang dibedakan dari kambing jantan (se'ir). Semuanya mereka persembahkan pada hari raya. Darah hewan korban ini dilemparkan ke sekeliling mezbah. Seluruh korban persembahan, korban keselamatan dan korban tebusan dan korban penghapus dosa itu dilumatkan pada mezbah, dicurahkan pada kaki mezbah, dan dalam beberapa kasus dipercikkan di dinding mezbah atau di atas bejana di dalam ruangan (King \& Stager, 2010, p. 408).

Meskipun mereka melakukannya dengan sungguh-sungguh dan teratur, tetapi karena Tuhan telah jemu, Ia tidak menginginkannya lagi. Persembahan korban daging, dengan bau harumnya, hanyalah bentuk secara simbolis. Secara substansif, mempersembahkan korban merupakan ekspresi luar dari ucapan syukur atas berkah Tuhan, atau kerinduan akan berkat-Nya, yang benar-benar mengikat dalam ketaatan terhadap kehendak-Nya. Akan Tetapi dalam kasus mereka, hal ini tidak memiliki arti yang seperti itu. Mereka menganggap bahwa dengan melakukan ritual persembahan korban ini, mereka telah menyenangkan Tuhan; dan karena itu, maka hal ini merupakan kekejian bagi Tuhan dan dikecam oleh Yesaya.

\section{Ibadah Perayaan}

Tuhan direndahkan oleh ibadat dan perayaan-perayaan yang mereka lakukan. Pada ayat 14 (terjemahan TB), kalimat "Perayaan-perayaan bulan barumu dan pertemuan-pertemuanmu yang tetap, Aku benci melihatnya; semuanya itu menjadi beban bagi-Ku, Aku telah payah menanggungnya. Gagasan sasaran pertama, yang diungkapkan "Aku tidak tahan" (lo'- 'uwkal): secara harfiah, kata ini adalah future hophal, bisa diartikan: saya tidak dapat, tidak mampu, untuk menanggung yang diberikan/dipersembahkan, yang juga terdapat dalam Maz.101:5; Yer. 44:22; Ams. 30:21); menjadi kasus absolut di sini, karena objek gramatikal lain menampilkannya dalam dua kata benda terakhir: kefasikan dan kerumunan yang indah.

Seperti bulan baru dan Sabat (yang terakhir selalu menandakan sabat mingguan saat ditafsirkan dengan kata chodesh), pada kenyataannya pemanggilan dalam pertemuan seluruh umat pada hari Sabat mingguan dan perayaan-perayaan merupakan kegiatan biasa dan rutin menurut Imamat 23 , dan TUHAN tidak tahan terhadap perayaan-perayaan yang terkait dengan kejahatan. Kata וְעִצָרָרה (waatsaaraah, dari akar kata aatsar, untuk menggambarkan kerumunan yang saling berdekatan) memiliki kesamaan dengan kata miq-raa', sejauh pemakaiannya segera diperhatikan seperti yang ditunjukkan oleh Yeremia 9: 1; seperti panee'guris, identik de- 
ngan ekkleesi'a- 'aawen (dari kata uwn, bernafas) adalah nilai moral yang tidak berharga, dianggap sama sekali tanpa adanya esensi dan nilai sejati di hadapan Allah. Nabi sengaja menggabungkan dua kata benda ini bersama-sama. Pertemuan perayaanperayaan yang meriah, dikombinasikan dengan kekosongan batin dan kesia-siaan pada pihak orangorang yang berkumpul bersama. Hal semacam ini merupakan sebuah kontradiksi dan pertentangan yang tidak dapat diterima Tuhan.

Seperti yang ditafsirkan oleh Bergant dan Karris, (Bergant \& Karris, 2002, p. 515) bahwa Yesaya sebenarnya tidak menentang dan menolak ibadah dan upacara-upacara keagamaan mereka, tetapi Yesaya mengatakan bahwa ritual dan ibadah perayaan itu penting dan perlu untuk melambangkan pertobatan dan pembersihan diri dari dosa. Namun ibadah dan upacara keagamaan akan benar kalau sesuai dengan substansi yang ingin diungkapkan, lewat perlakuan dan tindakan secara nyata dalam hidup mereka sehari-hari. Pada ayat 14 (terjemahan harfiah), Allah memberikan kecaman yang sangat keras terhadap mereka: Bulan-bulan baru dan perayaanperayaanmu, semua itu telah menjadi beban bagiKu; Aku lelah menanggungnya. Kalimat ini memiliki makna bahwa jiwa (nephesh) orang-orang yang berkumpul itu belum menyatukan hidup jasmani dan rohani, yang tidak memiliki prinsip kesadaran diri sendiri, seolah-olah lingkaran kesadaran diri untuk memahami seluruh hakikat keberadaan-Nya tidak berasal dari keinginan dan motivasi yang berasal dari dalam diri yang tulus.

Jadi, menurut gambaran yang diambil pada manusia seperti dari dewa, jiwa (nephesh) Allah, seperti ungkapan jiwa-Ku, menunjukkan pusat keberadaan-Nya, yang dianggap dikelilingi dan dipuja (dipersonalisasi) oleh kesadaran diri; dan oleh karena itu, apapun yang dibenci Tuhan (Yer. 15:1) atau yang dicintai (Yes.42:1), dibenci atau dicintai di kedalaman yang paling dalam dalam batas-batas kehendak-Nya. Jadi, Dia membenci semua perayaan-perayaan yang dilakukan di Yerusalem, apakah perayaan bulan baru, atau hari raya (menurut Im. 23, hari Sabat juga termasuk). Untuk waktu yang lama, perayaan mereka telah menjadi beban dan menjengkelkan Allah: karena hal itu peribadatan yang kosong dan sangat membebani Allah.

\section{Tuhan juga Menolak Doa-doa kaum Yehuda}

Kebenaran diri mereka, sejauh hal itu bergantung pada pengorbanan dan penghormatan terhadap perayaan maupun ritus, sekarang dipermalukan, ditolak dan dikecam oleh Tuhan. Benteng suci mereka sebagai bangsa pilihan Allah dihancurkan oleh kepalsuan ibadah mereka. Pada ayat $15 \mathrm{~b}$, (terjemahan TB) dengan tegas TUHAN mengatakan Apabila kamu menadahkan tanganmu untuk berdoa. KJV: And when ye spread forth your hands, dan terjemahan harfiah: Apabila kamu menadahkan tanganmu dan berdoa dengan sangat tekun. Ketiga terjemahan menekankan pentingnya untuk memperhatikan hal-hal lahiriah ketika menghadap atau menyembah-Nya. Tentu harus dipahami bahwa hal ini dalam konteks ritual dan kultus penyembahan secara khusus dan konteks ibadah secara umum. Maka terjemahan ini mengatakan bahwa betapapun mereka telah berdoa dengan cara yang paling benar, Tuhan tidak berkenan melihatnya. Terjemahan harfiah lebih jelas lagi, di mana disini ditambahkan kata dengan sangat tekun. Terjemahan ini mempertegas bahwa, doa yang sangat benar dan tulus serta dengan kesungguhan yang penuh untuk memohon, Allah tetap tidak mempedulikannya dan menolak sebab dosa dan kejahatan terhadap sesama telah menghalanginya.

Pada ayat ini terdapat kritik aparatus pada

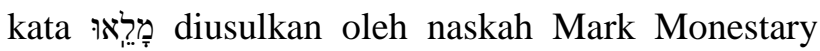
Volume I tahun 1950. Usulan ini menyarankan kata מָלָאטוּ (qal perf.) artinya "dipenuhi” dipertimbangkan atau dibandingkan pemakaiannya dengan kata אצבעותיכם tangan berdarah. Teks yang dipermasalahkan ini perlu diperhatikan mengingat keseriusan kejahatan sosial yang terjadi di Yehuda. Dalam hal ini, makna kata tangan berdarah dengan tangan dipenuhi darah memiliki kedalaman makna yang berbeda. Kata tangan berdarah berarti tangan bersalah, berdosa 
atau tangan melakukan perbuatan kejahatan. Sementara kata tangan dipenuhi darah berarti kejahatan yang dilakukan adalah kejahatan besar, kejahatan luar biasa yang terjadi secara terang-terangan. Sebagaimana terjemahan versi KJV memakai kata full of blood, maka kata yang lebih tepat untuk menggambarkan kejahatan sosial dalam konteks ini ada-

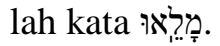

Doa-doa yang mereka panjatkan sebagai bentuk perasaan religius, untuk menjaga hubungan dengan Allah yang kudus serta untuk memperbaiki hubungan dengan Tuhan menjadi penipuan karena dosa kejahatan sosial yang begitu berat yang mereka lakukan dan secara tegas ditolak Tuhan. Sementara hakekat doa adalah ungkapan fundamental dari hubungan sejati dengan Tuhan. Oleh karena itu, karena kebejatan moral Yehuda, nabi Yesaya datang untuk memperingatkan, supaya bisa melacak kembali kesungguhan doa mereka akibat tipuan yang diperbuat. Dosa yang begitu berat itu telah merusak pondasi perjanjian, karena ketiadaan makna doa-doa yang mereka sampaikan (Stanislaus, 2018, p. 78).

Situasi yang buruk sekali dan berbalik dari hakekat doa secara nyata terjadi dalam kehidupan sosial Yehuda. Banyak tindakan pemerasan, perbudakan, dan melecehkan orang-orang lemah secara sosial. Di mata Tuhan, semuanya itu serupa dengan pembunuhan dan penumpahan darah. Bukan berarti

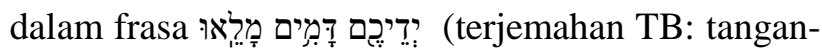
mu dipenuhi dengan darah), kata-kata itu memiliki makna bahwa di tangan mereka benar-benar ada darah saat mereka membentangkan tangan mereka dalam doa. Tetapi di hadapan Tuhan, apa yang mereka lakukan adalah hanya sebagai pertunjukan lahiriah untuk menyembunyikan sifat dan sikap yang sebenarnya. Betapapun bersihnya mereka bahkan mungkin telah mencuci dirinya sendiri, tetapi tangan mereka tetap meneteskan darah bagi yang lemah. Tuduhan ini dengan sangat jelas telah dinyatakan secara negatif di ayat 11-15. Tuhan tidak dapat menanggung perbuatan mereka. Oleh karena mereka melakukan pemujaan yang benar, tetapi dicemari dengan perbuatan yang tidak benar, bahkan mem- bunuh sesamanya. Semua yang mereka banggakan adalah kesalehan diri yang palsu dan menipu.

\section{Tuhan Menginginkan Pertobatan dari Yehuda}

Pada ayat 17 , tiga hal yang ditekankan berhubungan dengan tindakan ke dalam diri: "Basuh dan bersihkanlah dirimu, jauhkanlah kejahatanmu dari hadapan-Ku dan berhentilah berbuat jahat. Dalam perbandingan terjemahan (KJV, TB dan terjemahan harfiah), tidak memliki perbedaan yang signifikan. Kalimat perintah ini bukan hanya sebagai bahasa kiasan yang literal, tetapi juga sangat menekankan pada apa yang dikehendaki-Nya. Peringatan pertama mensyaratkan yang terutama adalah penyucian dari dosa-dosa yang dilakukan. Ini adalah syarat untuk memperoleh pengampunan (Bergant \& Karris, 2002) Cuci: rachatzu, dari kata râchatz, memiliki arti secara umum "melakukan pencucian diri secara serius". Bersihkan dirimu, dipakai kata hizzaccu. Kata ini adalah kata kerja dengan nada penekanan pada suku kata terakhir. Kata kerja semacam itu secara umum dan tentu saja untuk mengatakan kepada orang-orang yang melakukan pembersihan (lihat Yes. 52:11; Bil. 17:10).

Menurut perbedaan antara kedua sinonim itu (membasuh diri sendiri dan membersihkan diri sendiri), yang pertama harus dipahami hal itu mengacu pada satu tindakan pertobatan yang hebat dari pihak orang yang berpaling kepada Tuhan, yang terakhir kepada pertobatan sehari-hari seseorang yang telah begitu berubah. Kedua nasihat ini mengharuskan mereka untuk menempatkan diri mereka dalam cahaya wajah ilahi, dan menyingkirkan perbuatan kejahatan yang mereka lakukan terhadap sesama, khususnya mereka yang termasuk ke dalam golongan yamg lemah. Mereka harus bergumul melawan kejahatan dan dosa mereka yang begitu hebat, sampai pada akhirnya dosa itu sepenuhnya lenyap.

Pada ayat 18, lima seruan yang berkaitan dengan praktik dan tindakan ke luar diri, dirumuskan dalam kalimat: belajarlah berbuat baik, usahakanlah keadilan, kendalikanlah orang kejam; belalah hak anak-anak yatim, perjuangkanlah perkara janda- 
janda. Peringatan pertama merupakan hal yang sangat mendasar. Semuanya kalimat ini merupakan bentuk imperatif aktif. Nasihat yang dimaksud ingin mengatakan tidak cukup hanya dengan niat baik, tetapi harus benar-benar berusaha dan menggumulinya, mengerahkan seluruh daya upaya dan pikiran untuk menuntaskannya. Pernyataan: Belajarlah untuk berbuat baik, dipakai dengan kata היيֵֵב (hetib) itu berarti si subyek (dalam bentuk kasus akusatif) belajar untuk mengubah kebiasaan lama yaitu status quo yang hanya memikirkan kepentingan dan keuntungan diri sendiri. Kemudian muncul himbauan yang kedua: Usahakanlah keadilan (dârash, seseorang yang mencurahkan perhatian secara khusus dan serius terhadap sesuatu hal dengan semangat dan ketekunan); dan ketiga, Kendalikanlah orang kejam. Ini berarti menyumbang/memberi kebenaran, seperti kata châmotz (dari kata châmatz, memiliki sikap yang tajam, jelas dan tegas) dan bukan orang yang pasif, tinggal berdiam, atau orang yang kehilangan haknya untuk berindak karena kebanyakan orang memiliki sikap diam dan mengambil posisi aman. Dalam perikop ini, dapat dipahami bahwa penindas dibicarakan, itu berarti orang Yehuda sebagai pelaku kejahatan maka harus mengarahkan diri ke jalan keadilan, menahan kemauan dengan hukuman dan memberlakukan disiplin yang berat dan ketat.

Kemudian dalam perikop ini, perhatian terhadap janda dan anak yatim sangat ditekankan. Janda dan anak yatim, serta orang asing, adalah umat Allah sesuai dengan hukum-Nya, maka Allah sangat memperhatikan dan mengutamakan pembelaan terhadap kaum-kaum yang demikian. Allah memberi perhatian khusus kepada mereka sebab anak yatim dan janda-janda adalah kelompok paling lemah dalam status sosial dan sistem kemasyarakatan bangsa Israel, sehingga tidak ada orang yang mau membela perkara mereka dan paling rentan terhadap pelanggaran hak asasi dari para penguasa (Stanislaus, 2018, p. 82).

Tuhan Menjanjikan Anugerah Pengampunan
Di ayat sebelumnya (10-15), TUHAN telah berbicara kepada umat-Nya dengan murka. Tetapi kemurahan hati-Nya dinyatakan dalam peringatan di ayat 16 dan 17. Sekarang oleh kemurahan-Nya, Ia tidak menginginkan kehancuran umat-Nya, tapi keselamatan yang sepenuhnya. Di ayat 18 , dalam versi Terjemahan Baru (TB), "Baiklah kita berperkara! firman TUHAN, Sekalipun dosamu merah seperti kirmizi, akan menjadi putih seperti salju; sekalipun merah seperti kain kesumba, akan menjadi putih seperti bulu domba". TUHAN di sini mengajak Yehuda untuk melakukan dan membuat kesepakatan. Kata nocach digunakan dalam pengertian timbal balik, dan dengan arti yang sama seperti nishpat dalam Yesaya 43:26. Dalam perjanjian seperti itu, Yehuda harus mengaku salah, karena kebenaran yang mereka klaim selama ini terletak pada ibadah yang siasia; dan sesungguhnya mereka melakukan kejahatan dan penindasan.

Berdasarkan dosa dan kejahatan yang telah mereka perbuat, maka sepantasnyalah kaum Yehuda dihukum. Namun TUHAN tidak akan memperlakukan umat-Nya sesuai dengan keadilan retribusinya. Namun menurut belas kasih-Nya yang bebas, Dia menyangkali hukuman-Nya, dan tidak hanya menganggap dosa itu tidak ada, tapi mengubahnya menjadi anugerah pengampuan oleh kasih-Nya. Bahkan dosa yang paling besar sekalipun diubahnya menjadi kemurnian.

Pada dua kata bentuk hiphil di sini diterapkan pada warna, yaitu warna merah dan putih. Representasi karya anugerah yang dijanjikan Tuhan sebagai perubahan dari warna merah menjadi putih, didasarkan pada simbolisme warna, sama seperti ketika orang-orang kudus dalam Wahyu (Why. 19: 8) digambarkan orang-orang kudus yang akan tinggal bersama-Nya berpakaian putih, sementara orangorang bebal mengenakan warna ungu dan merah tua (Yes. 17: 4). Dalam hal ini, pada umumnya dianggap bahwa Yesaya berbicara tentang warna merah sebagai warna dosa, karena dosa berhubungan dengan kejahatan; dan ini sepenuhnya benar, meski tidak bisa digeneralisir di semua konteks. Dosa dise- 
but merah, karena ini adalah ibarat panas yang membakar (Oswalt, 2000).

Jika ditelisik dan dihubungkan dengan makna anugerah, selain sebagai pemberian hanya oleh Allah, anugerah pengampunan juga merupakan awal, efek dan proses pada keselamatan (Lukito, 2002, p. 54). Kebaikan dan kasih Allah dicurahkan kepada orang berdosa dan orang yang seharusnya dihukum. Memang, menurut pandangan Alkitab, bahwa dosa bertolak belakang dengan apa yang berkenan kepada Allah, dan kemurkaan-Nya yang kontra dengan kasih atau anugerah-Nya. Akan tetapi, hal itu Ia lakukan sesuai dengan sifat, karakter dan hakekat-Nya yang penuh kasih, dan Ia melakukannya secara bebas dan berdaulat.

TUHAN menawarkan kepada kaum Yehuda sebuah Anugerah Ilahi, yang dari-Nya akan dinyatakan dengan rahmat, walaupun TUHAN telah memutuskan bahwa kematianlah yang layak bagi mereka oleh karena dosa-dosa mereka. Kebenaran itu adalah putih seperti salju dan seperti bulu domba, oleh anugerah-Nya, Yehuda dimurnikan. Ini adalah karunia yang diberikan kepada umat-Nya karena belas kasih-Nya, tanpa tergantung pada hukum apapun.

\section{Tuhan Memberkati orang yang Bertobat tetapi Menghukum yang tidak Taat}

Tetapi setelah restorasi Yehuda secara integral oleh tindakan kasih karunia Allah, selebihnya akan bergantung pada perilaku umat sendiri. Allah akan menentukan masa depan Yehuda (ayat 19, 20). Pernyataan "Jika kamu mau mendengarnya, kamu akan makan hasil yang baik di tanah ini, jika kamu memberontak (dengan keras), kamu akan dimakan pedang. Sungguh, TUHAN yang telah mengucapkannya", merupakan memberikan pilihan kembali kepada kaum Yehuda. Setelah pembenaran Allah terhadap mereka, berkat dan kutuk itu diletakkan sekali lagi sebelum mereka dibenarkan, karena keduanya hal ini sudah lama diproklamirkan oleh hukum Taurat (bandingkan ayat 19b dengan Ul. 28: 3 dst, Im. 26: 3 dst, dan ay 20b dengan ancaman pemba- lasan akan dimakan dengan pedang di Im. 26:25). Janji memakan yang baik, yaitu kenikmatan berkat materi.

Tetapi di sisi yang lain, jika umat memberontak dan melawanan ketetapan Allah, maka mereka akan mendapat kutukan dan dimakan dengan pedang. Dalam klausa bersyarat, kedua hal itu diikuti oleh hal presentis (bandingkan Im. 26:21), karena hal menaati dan memberontak keduanya merupakan konsekuensi dari tindakan kehendak. Jika mereka memang bersedia, maka sebagai akibat dari ketaatan ini mereka akan diberkati; dan jika mereka menolak, dan memberontak terhadap Allah, maka mereka mendapat kutuk. Oleh karena itu, Yesaya benar-benar berbicara dengan sangat jelas mengenai akibat dan konsekuensinya. Oleh karena itu, pilihan dari yang Ilahi sekarang disediakan, walaupun kaum Yehuda terlalu rusak karena dosa dan kejahatan yang mereka lakukan di hadapan Allah yang kudus. Solusinya satu-satunya adalah dengan jalan berdamai karena perselisihan antara TUHAN dan umat-Nya sebenarnya tidak diharapkan. Frasa "sungguh, TUHAN yang mengucapkannya" menandakan dan menekankan: 1) Karakter Allah yang tidak pernah berubah, 2) karakter Allah yang berbelas kasihan, 3) mempercayai janji-janji-Nya dan 4) keakuratan dari wahyuNya.

Meskipun kaum Yehuda dinyatakan telah berdosa di hadapan Allah, tetapi Ia tetap memberikan pilihan kepada Yehuda. Oleh kemurahan Allah, Ia tidak peduli sebesar apapun dosa dan kejahatan mereka, sebab Allah mampu menyucikan mereka dan mengembalikan mereka sebagai orang-orang yang suci dan benar sebagai umat perjanjian. Nasib bangsa itu tergantung kepada respon mereka terhadap anugerah pengampunan ini. Jika mereka mau meninggalkan dosa dan kejahatan mereka, maka mereka akan menerima anugerah pengampunan Allah (Pfiiffer, 2009, p. 440). Allah pasti menunjukkan dan memateraikan kemurahan-Nya dengan memberi mereka berkat-berkat lahiriah seperti keberhasilan dan kelimpahan serta akan melindungi mereka dari musuh-musuh yang datang menyerang. Tetapi jika 
mereka menolak dan memberontak terhadap kedaulatan Allah, maka mereka akan ditimpa kesusahan dan malapetakalah yang akan mereka hadapi.

\section{Relevansinya}

\section{Kejahatan Sosial adalah Dosa yang Bertentangan} dengan Hakekat Kekudusan Allah

Alkitab mendefenisikan dosa sebagai pelanggaran terhadap hukum Taurat, anomi, keadaan tanpa hukum (1 Yoh. 3:4). Perbuatan, perkataan, pemikiran atau keinginan bukanlah dosa, tetapi menjadi dosa jika tidak sesuai dengan hukum Tuhan. Apakah sesuatu hal merupakan dosa atau tidak, bukan ditentukan oleh penilaian atau perasaan manusia melainkan ukurannya adalah apakah hal itu sesuai atau tidak sesuai dengan Firman dan keinginan Allah. Dosa adalah pelanggaran terhadap kehendak Allah, karena itu berbuat dosa berarti melakukan apa yang dilarang Allah (Kej. 2:17) atau tidak melakukan apa yang diperintahkan-Nya (Yak. 4:17), atau tidak menjadi seperti apa yang Allah inginkan dari manusia (Im. 19:2). Jadi, dosa adalah penolakan terhadap aturan-aturan Allah dan ketidaktaatan terhadap kehendak-Nya (Koehler, 2010, p. 66).

Browning (Browning, 2007, p. 84), memperjelas bahwa apapun yang salah dalam hubungan manusia dengan Allah adalah dosa (Rm. 14:23). Semua orang dirasuki oleh dosa dan kesalahannya dan keadaan ini tidak dapat diubah oleh upaya manusia (Rm. 7) dan hanya oleh prakarsa Allah maka suatu perubahan dapat terjadi (Yoh. 3:3). Secara mendasar dosa itu telah ditaklukkan oleh hidup, kematian dan kebangkitan Yesus. Orang percaya dilepaskan dari kuasanya yang membelenggu manusia oleh persekutuan manusia dengan Kristus dalam iman dan pengharapan. Salah satu hakekat Allah adalah Kudus. Maka dalam kekudusan-Nya, Ia mengharapkan umatNya menjauhi serta membenci dosa khususnya dosa kejahatan sosial, dengan melakukan kebaikan dan berlaku adil sebagai perwujudan keadilan sosial.

\section{Ibadah yang berkenan bagi Tuhan adalah yang Membuahkan Kebenaran dan Keadilan}

Masalah kebenaran dan keadilan adalah suatu aspek yang terus terjadi di segala zaman. Sejak zaman Perjanjian Lama, Alkitab dengan sangat serius menekankan untuk berlaku adil terhadap sesama, baik sesama orang Israel bahkan kepada orang asing sekalipun. Sehingga keadilan menjadi salah satu hal yang masuk ke dalam "Kumpulan Hukum Kekudusan" bagi orang Israel (Mamahit, 2010, p. 12). Lebih khusus pada zaman nabi-nabi, hal ini mendapat perhatian serius dari para nabi. Sebagaimana ketidakadilan yang marak terjadi di kerajaan Selatan yang disoroti oleh Yesaya, pada saat yang sama ketika nabi Amos melayani, hal yang sama juga menjadi masalah utama di kerajaan Utara (Purba, 2012, p. 44).

Keadilan merupakan nilai-nilai dasar yang menggerogoti hati nurani manusia yang peka terhadap masalah sosial yang sedang terjadi di masyarakat umum. Kegelisahan ini muncul akibat dan konsekuensi dari hubungan manusia dengan Allah yang adil dan benar itu. Kebenaran dan keadilan merupakan sifat dan hakikat dari Allah, dan hal inilah yang mendasari segala perbuatan-Nya. Apa yang sudah diputuskan dan ditegakkan oleh Allah dalam keadilan-Nya, Ia pertahankan dengan pasti. Akhirnya dapat dipahami bahwa kata Ibrani Syalom mempunyai arti yang lebih dari sekedar damai, tanpa perselisihan, tetapi mencakup keseluruhan, yaitu kesejahteraan yang menyeluruh, keadaan yang sehat dan keharmonisan seperti yang Allah inginkan (Wright, 2010, p. 137). Dengan demikian, syalom erat hubungannya dengan keadilan dan kebenaran, yang menyebut hal-hal dan orang-orang sebagaimana seharusnya yang Allah inginkan.

Maka gereja adalah sarana Allah untuk memberitakan suara kenabian dan gereja seharusnya bisa menjadi wujud penyataan kasih Allah. Melalui gereja, penyataan kasih Allah dapat terwujud bagi dunia ini yaitu untuk melaksanakan dan mewujudkan kebenaran dan keadilan sabagaimana sifat Allah. Sejatinya gereja dapat mengetahui dan me- 
nyadari hakekat dan substansi ibadah yang sesungguhnya untuk menghadirkan, mengusahakan dan mewujud nyatakan kebenaran dan keadilan bagi mereka yang termarginalkan. Dengan kesadaran yang demikian, orang percaya sebagai gereja dituntut memiliki kegelisahan dan peka terhadap masalah-masalah sosial yang terjadi.

Balasuriya (2011, p. 278) mengungkapkan keprihatinannya terhadap gereja masa kini. Ia melihat gereja tidak selalu menyadari dan menjadikan keadilan dan kebenaran sebagai yang paling pokok bagi kehidupan spritualnya. Maka tak jarang muncul pemikiran dan tindakan dari orang yang mengaku diri sebagai orang Kristen, nyatanya hidup bertentangan dengan hukum Allah dan menghambat tuntutan keadilan sosial. Ibadah dan cara beragama seperti: berdoa, bergereja, memberikan persembahan, merayakan hari-hari besar gerejawi bahkan bermeditasi adalah cara-cara konvensional yang tidak akan memiliki arti, jika tidak terimplimentasi dalam tindakan sehari-hari. Oleh karena itu, salah satu tujuan pokok dari komitmen pada keadilan dan kebenaran tidak cukup hanya spritual dan supernatural saja. Maka gereja dalam melihat ibadah, seharusnya menjadi sarana dan sumber yang tidak habis-habisnya menjadi motivasi untuk melakukan keadilan dan kebenaran di tengah-tengah pergumulan dan kesenjangan sosial yang semakin kompleks.

\section{Gereja sebagai Mitra Allah sejatinya Aktif untuk} Membela dan Memperjuangkan Kaum Lemah

Wibowo (2016, p. 82) mengutip pernyataan Paus Fransiskus dalam Ensiklikn Laodato Si ditandatangani pada hari Pentakosta tanggal $24 \mathrm{Mei}$ 2015 mengatakan bahwa pembebasan kaum miskin dan tertindas merupakan tugas seluruh umat Kristiani. Setiap orang Kristen dan setiap komunitas dipanggil sebagai sarana Allah untuk membebaskan dan memajukan kaum lemah, dan untuk memampukan mereka menjadi bagian masyarakat sepenuhnya. Inilah wujud konkret keberpihakan gereja pada orang-orang miskin dan lemah, yaitu memberikan kemungkinan untuk menjadi bagian dalam masyarakat secara utuh. Keberpihakan ini dinyatakan da- lam solidaritas baru bersama orang lemah dan yang tertindas dengan mengupayakan hidup mereka menjadi lebih bermartabat. Gereja tidak hanya diundang untuk memberi makan kepada orang-orang miskin, mengikuti perintah Yesus (Mrk. 6:37), tetapi menjamin bagaimana orang yang terpinggirkan mendapat nafkah yang bermartabat, bahkan agar semua orang mencapai kesejahteraan dalam segala aspek, termasuk di dalamnya akses terhadap pendidikan, pelayanan kesehatan dan pekerjaan. Oleh karena itu, segala bentuk diskriminasi terhadap orang-orang lemah merupakan kondisi yang harus diperangi.

Bagi Paus Fransiskus, keberpihakan kepada kaum miskin dan lemah bukanlah soal kemanusiaan saja, tetapi juga masalah teologis. Wibowo juga mengutip pendapat Gustavo Guiterez yang mengatakan: "Keberpihakan kepada mereka yang lemah dan tertindas dapat disebarkan melalui tiga dimensi yaitu mengikuti Kristus, karya teologis dan pewartaan Injil. Solidaritas dengan kaum lemah dan terpinggirkan berarti mengakui martabat kemanusiaan mereka secara penuh sebagai anak-anak Allah serta mengakui bahwa mereka mempunyai hak untuk mengatur kehidupan mereka sendiri (Wibowo, 2016, p. 87). Maka dalam hal ini betapa penting untuk mendengarkan jeritan mereka, karena sabda Allah mengajarkan "sesungguhnya segala sesuatu yang kamu lakukan untuk salah seorang dari saudara-Ku yang paling hina ini, kamu telah melakukannya untuk Aku" (Mat. 25:40). Sebagaimana yang diungkapkan oleh Ma-ngunwijaya (2004, p. 97), Injil dengan jelas menyampaikan bahwa iman sejati tidak semata-mata merupakan suatu sikap dasar atau kepercayaan batin, tetapi harus menjadi nyata dalam semua tindakan dan seluruh kehidupan, baik perorangan maupun sosial. Tanpa perwujudan yang nyata itu, iman hanya melayang-layang dan tidak sungguh berakar. Gereja harus memberi respon dan berkontribusi untuk mewujudkan masyarakat yang adil dengan diresapi oleh hukum kasih. Orang percaya sebagai gereja, tidak bisa memaafkan diri lagi dengan berdalih bahwa gereja tidak mengetahui tuntutan itu. Gereja wajib menggunakan segala kemungkinan daya dan upaya 
yang ada dalam tangan manusia, demi tujuan itu, sebab landasan kasih adalah keadilan. Injil tentang penebusan dan pembebasan semua manusia dan bangsa, terutama mereka yang tertindas, miskin dan tersingkir, hanya bisa dimengerti, dipercaya dan barangkali diterima, kalau mereka didatangi dan disapa di tengah kesusahan dan penderitaan yang menimpa mereka. Kalau pewartaan itu tidak disertai dengan kesaksian dan keterlibatan yang nyata, maka Injil akan dianggap omong kososng dan takhyul yang sudah usang saja.

Nugroho (2019, p. 107) mengatakan: "gereja dalam tugas dan panggilannya, harus menyuarakan serta memperjuangkan keadilan dan hak-hak orang miskin". Kalau gereja, anggota-anggota dan lembaga-lembaganya tidak mengungkapkan cinta kasih Allah kepada yang lain dengan ikut serta dalam proses konstruktif terhadap keadaan manusia saat ini, maka gereja akan disamakan dengan pelaku ketidakadilan dan penindasan. Jika demikian, maka gereja tidak lagi memiliki fungsi dan makna. Andai kata demikian halnya, maka gereja akan lenyap, dalam arti manusiawi lenyap, sebab adanya gereja semacam ini tidak mempunyai arti lagi bagi manusia saat ini.

\section{Gereja dan Persinggungan Keadilan Sosial di Indonesia}

Fakta sosial Indonesia secara gamblang memperlihatkan masalah sosial begitu mendominasi kehidupan sebagian besar masyarakat. Kemiskinan, pemiskinan, ketidakadilan, persekusi, pemaksaan kehendak, pelecehan, manipulasi hukum dan kejahatan sosial lainnya begitu banyak terjadi di negara ini. Di tengah realitas sosial semacam ini, gereja di Indonesia perlu terlibat untuk menguraikan berbagai masalah tersebut hingga menemukan solusi dan jalan keluar yang terbaik (Nugroho, 2019, p. 111). Merujuk pada kitab Yeremia 29:7 yang berisi "Usahakanlah kesejahteraan kota ke mana kamu Aku buang, dan berdoalah untuk kota itu kepada TUHAN, sebab kesejahteraannya adalah kesejahteraanmu”. Gereja sebagai mitra Allah di dunia harus berjubahkan keadilan dan kebenaran, karena hakekat Allah adalah keadilan dan kebenaran.

Kehadiran dan keberadaan gereja-gereja di Indonesia sudah saatnya keluar dari gedung dan turun mimbar untuk melakukan pelayanan langsung di masyarakat sebagai tanggung jawab sosialnya. Sikap gereja yang tidak peduli kepada mereka yang mengalami ketidakadilan sosial, itu sama saja menindas, mengabaikan dan pengingkaran terhadap Tuhan, dan jelas hal ini menyakiti hati-Nya. Masalah ketidakadilan sosial, khususnya kemiskinan merupakan masalah kemanusiaan yang sangat serius hari ini di Indonesia yang penanggulangannya bukan saja menjadi tanggung jawab pemerintah, tetapi juga mestinya bagian dari misi transformatif gereja-gereja di Indonesia (Susanto, 2019, p. 51). Sebab masalah-masalah sosial merupakan masalah teologis yang dihadapi gereja secara empiris.

Hal ini merupakan peringatan nyata bagi gereja-gereja di Indonesia, untuk melihat dirinya supaya berani hadir sebagai pembela di tengah-tengah pergumulan kaum yang lemah. Dengan tanpa mengabaikan ketaatan dan ibadah-ibadah ritual, sebab hal itu juga bentuk ketaatan kepada Tuhan, gereja-gereja di Indonesia jangan sampai mengabaikan pergumulan dan masalah-masalah kemanusiaan utamanya bagi mereka yang termarginalkan. Gereja adalah sarana dan perpanjangan tangan Tuhan di dunia untuk menolong dan membela umat-Nya. Gereja dengan segala program-programnya hadir untuk membebaskan mereka yang lemah, yang miskin dan bagi mereka yang menjadi korban ketidakadilan sosial sehingga kuasa dan kasih Kristus menjadi nyata dan dialami oleh masyarakat Indonesia.

Tanggung jawab sosial gereja merupakan bagian dari iman kepada Yesus Kristus dan kasih kepada sesama manusia sehingga menjadi sangat penting untuk merealisasikan kehadiran Allah bagi kaum yang lemah. Tugas panggilan gereja (diakonia) perlu bahkan wajib direfleksikan dan diimplementasikan sebagai bagian dari kehidupan bergereja. Gereja-gereja di Indonesia sejatinya berdampak dan berkontribusi terhadap kaum yang lemah dan me- 
reka yang mudah menjadi korban. Maka dalam hal ini gereja-gereja di Indonesia sebaiknya bekerja sama dan bermitra dengan pemerintah untuk mengupayakan pemberantasan masalah-masalah sosial yang sedang dan yang akan terjadi. Gereja harus berani bersikap dan bersuara bahkan mengkritik kebijakan-kebijakan pemerintah yang tidak pro kepada kaum kecil. Dengan demikian, gereja-gereja di Indonesia turut membela dan memberdayakan masyarakat akar rumput.

\section{KESIMPULAN}

Allah mengecam kaum Yehuda dikarenakan baik rakyat maupun pemimpin (di bawah pimpinan raja Ahaz yang jahat) mereka telah murtad dan membelakangi Allah. Hal ini terbukti karena maraknya penindasan, pemerasan, pembiaran dan kejahatan sosial lainnya terhadap orang-orang lemah seperti orang miskin, janda dan anak yatim. Oleh karena kejahatan itu, Allah menyamakan mereka dengan warga Sodom dan Gomora. Karena kejahatan-kejahatan mereka, Allah menolak persembahan korban, dan membenci semua perayaan-perayaan keagamaan bahkan tidak mendengar doa-doa yang mereka panjatkan. Sebab bagi Allah semuanya itu adalah kemunafikan, dan penghinaan terhadap Allah yang Kudus. Allah yang Maha Kudus tidak dapat ditipu apalagi disuap oleh orang-orang yang jahat dengan segala macam persembahan dan peribadatan. Per-

\section{DAFTAR RUJUKAN}

Balasuriya, T. (2011). Teologi Siarah. Jakarta: BPK Gunung Mulia.

Baxter, J. S. (2002). Menggali Isi Alkitab 2 Ayub Sampai dengan Maleakhi. Jakarta: Yayasan Komunikasi Bina Kasih.

Bergant, D., \& Karris, R. J. (2002). Tafsir Alkitab Perjanjian Lama. Kanisius: Yogyakarta.

Boyd, F. M. (2000). Kitab Nabi-nabi Kecil. Malang: Gandum Mas.

Browning. (2007). Kamus Alkitab. Jakarta: BPK Gunung Mulia. sembahan yang tepat sekalipun bisa jadi penghinaan bagi Tuhan jika dipersembahkan oleh orang-orang yang tidak peduli terhadap sesama. Memberikan persembahan, taat beribadah dan berdoa dengan sungguh kepada TUHAN, tetapi tidak meninggalkan jalan-jalan, maksud dan keinginan yang jahat sama halnya menginjak-injak pelataran Bait Suci Allah yang artinya menghina kekudusan dan kemuliaan Allah. Kejahatan Yehuda yang kentara itu adalah kejahatan sosial yang membuat mereka benar-benar berdosa di mata Tuhan.

Tetapi Allah yang Kudus adalah Allah yang setia terhadap Perjanjian-Nya. Ia menunjukkan kemurahan dan kasih-Nya dan menerapkan janji-Nya untuk menyucikan dan menerima kembali orangorang yang mau datang kepada-Nya melalui jalan yang telah ditetapkan; yaitu mereka yang meninggalkan dosa dan kejahatan terhadap sesama. Pertobatan itu dilakukan dalam hidup untuk melakukan dan mengusahakan kebenaran, keadilan dan keberpihakan kepada mereka yang ditimpa kesusahan dan penderitaan. Kemudian memiliki tujuan yang konsisten dan sungguh-sungguh untuk menerapkan prinsip-prinsip keadilan sosial dalam tindakan yang konkret terlebih kepada orang-orang yang mudah menjadi korban, yang tak berdaya karena memiliki status sosial rendah dan orang yang tidak dapat membela diri karena kebijakan yang tidak berpihak.

Bullock, C. H. (2014). Kitab Nabi-nabi Perjanjian Lama. Malang: Gandum Mas.

Couey, J. B. (2014). The Disabled Body Politic in Isaiah 3: 1, 8. Journal of Biblical Literature, 133, No. 1, 95-109.

Gemeren, W. A. V. (2007). Penginterpretasian Kitab Para Nabi. Surabaya: Momentum.

Hill, A. E., \& Walton, J. H. (2001). Survei Perjanjian Lama. Malang: Gandum Mas.

King, J. P., \& Stager, L. E. (2010). Kehidupan Orang Israel Alkitabiah. Jakarta: BPK Gunung Mulia. 
Koehler, W. A. E. (2010). Intisari Ajaran Kristen. Pematang Siantar: Akademi Lutheran Indonesia.

Lasor, W. S., Hubbard, D. A., \& Bush, F. W. (2012). Pengantar Perjanjian Lama 2 Sastra dan Nubuat. Jakarta: BPK Gunung Mulia.

Lukito, D. L. (2002). Kekeliruan Pengertian Konsep Anugerah dalam Teologi dan Pelayanan Praktis. Veritas, 3, No.2, 149-170.

Lumintang, S. I. (2016). Theologia Penelitian dan Penelitian Theologis. Jakarta: Geneva Insani Indonesia.

Mamahit, F. Y. (2010). Teologi dan Praksis Keadilan Dalam Kitab Taurat. Veritas, 11 No. 1, 1-21.

Mangunwijaya, Y. B. (2004). Keprihatian Sosial Gereja. Yogyakarta: Kanisius.

Ngahu, S. S. T. (2019). Menguak Prasangka Homoseksualitas Dalam Kisah Sodom dan Gomora (Kajian Hermeneutik Kejadian 19:1-26). Gema Teologika, 4 No. 1, 17-30.

Nugroho, F. J. (2019). Gereja dan Kemiskinan: Diskursus Peran Gereja di Tengah Kemiskinan. Evangelical: Jurnal Teologi Injili Dan Pembinaan Warga Gereja, 3, No. $1,100-112$.

Oswalt, N. J. (2000). The New International Commentary On The Old Testament: The Book Isaiah Chapter 1-39. Michigan: Grand Rapids.

Pandia, E. (2016). Ibadah dan Keagamaan Israel Kuno. Kerusso: Jurnal Teologi Dan Pendidikan Agama Kristen, 15, No.1, 1-25.
Pfiiffer, F. C. (2009). Tafsiran Alkitab WycliffeVolume 2 Ayub-Maleakhi. Malang: Gandum Mas.

Purba, K. (2012). Keadilan Allah Menurut Kitab Amos Serta Relevansinya Bagi Kaum Miskin. STAKPN Tarutung, Tarutung.

Saragih, A. (2014). Hubungan Ibadah Dengan Keadilan ( Studi Eksegetis Amos 5:21-24) dan Relevansinya Bagi Umat Kristiani. STAKPN Tarutung, Tarutung.

Sitompul, A. A., \& Beyer, U. (2002). Metode Penafsiran Alkitab. Jakarta: BPK Gunung Mulia.

Snell, D. C. (2009). Kehidupan di Timur Tengah Kuno 3100-332. Jakarta: BPK Gunung Mulia.

Stanislaus, S. (2018). Kritik Sosial Nabi IsraelYehuda. Logos: Jurnal Filsafat Teologi, 15, No.1, 65-108.

Susanto, H. (2019). Gereja sebagai Umat Allah dan Rekan Negara. Jurnal Jaffray, 17 No.1, 3556.

Utley, B. (2010). Kumpulan Komentari Panduan Belajar Perjanjian Lama. Texas: Bible Lessons International.

Vriezen, TH. C. (2003). Agama Israel Kuno. Jakarta: BPK Gunung Mulia.

Wibowo, S. W. (2016). Teologi yang Membebaskan dan Membebaskan Teologi. Jakarta: Yayasan Taman Pustaka Kristen Indonesia.

Widyapranawa, S. (2012). Tafsiran Alkitab Kitab Yesaya Pasal 1-39. Jakarta: BPK Gunung Mulia.

Wright, C. (2010). Hidup Sebagai Umat Allah Etika Perjanjian Lama. Jakarta: BPK Gunung Mulia. 